\title{
Ontwikkeling van stotteren: Inleiding tot een praktijkmodel
}

\author{
Bert J.E.G. Bast ${ }^{1}$, Leonoor C. Oonk ${ }^{1}$, Luc De Nil ${ }^{2,3}$, Else Eising ${ }^{4}$, \\ Simone P.C. Koenraads ${ }^{5}$, Jan Bouwen ${ }^{5}$, Marie-Christine Franken ${ }^{5}$ \\ ${ }^{1}$ StotterFonds, Nijkerk \\ ${ }^{2}$ Department of Speech-Language Pathology, University of Toronto, Canada \\ ${ }^{3}$ Rehabilitation Sciences Institute, University of Toronto, Canada \\ ${ }^{4}$ Taal en Genetica Afdeling, Max Planck Instituut voor Psycholinguistiek, Nijmegen \\ ${ }^{5}$ Erasmus MC, Afdeling KNO, Gehoor-en Spraakcentrum, Rotterdam
}

\begin{abstract}
Samenvatting
Dit artikel is de inleiding op het direct hierna volgende (Oonk e.a. 2022) waar een nieuw praktijkmodel over het ontstaan en ontwikkeling van stotteren wordt voorgesteld.

In de dagelijkse praktijk van vooral Nederlandstalige logopedisten (-stottertherapeuten) is tot nu toe veel gebruik gemaakt van het klinische werkmodel van Bertens (1994; 2017). Dit model gaat uit van een primaire neuromusculaire timingsstoornis, welke zich niet alleen uit in het spreken, maar ook in algemene zin aanwezig is. Dit model echter, is aan revisie toe. Volgens de recente literatuur is de algemene aard van die timingstoornis niet bewezen, en zijn er veel vroegere (meer primaire) factoren aantoonbaar van belang bij het ontstaan van stotteren, met name in de genetica en in de neurologie. In dit artikel wordt deze literatuur kort samengevat, alsmede worden enkele recente modellen omschreven. Met name regulatie en terugkoppeling krijgen in recente modellen meer aandacht. Er is geen volledigheid nagestreefd, maar dit artikel is meer een tutoriale opmaat voor het hierna te presenteren model.
\end{abstract}

\section{Summary}

This article serves as an introduction to the accompanying paper, in which a new clinical model of the origin and development of stuttering is presented (Oonk e.a., 2022).

In their clinical practice, Dutch speech language pathologists still tend to use the clinical model proposed by Bertens $(1994 ; 2017)$. This model explains stuttering as developing from a primary neuromuscular timing deficit, which manifests itself not only in speech, but in more general behaviour as well. In our opinion, this model needs to be updated and revised based on current scientific and clinical knowledge. There is little

Correspondentieadres:

Dr. Bert Bast

StotterFonds

Nijkerk

E-mail: bbast@kpnmail.nl
Dit artikel is gelicentieerd onder de Creative Commons CC BY-NC-ND 4.0 (NaamsvermeldingNietCommercieel-GeenAfgeleideWerken) Internationale Licentie. Gebruik en distributie voor commerciële doeleinden en elke distributie van aangepast materiaal vereist schriftelijke toestemming. 
evidence for the general timing deficit in Bertens' model and, moreover, several more fundamental factors, especially those related to genetics and neural processes, that have an important role in the onset of stuttering have been reported. This paper provides a review and summary of these recent data, and several newer models are described. An important aspect of these models is the importance given to processes of regulation and feedback. An exhaustive overview of the existing literature has not been strived for but it is hoped that this paper will serve as a useful introduction to the clinical model presented in the accompanying paper.

\section{Inleiding}

Stotteren is een wijze van spreken die gekenmerkt wordt door de aanwezigheid van onvloeiendheden. Het begint meestal tijdens de peuterleeftijd maar herstelt vaak met of zonder therapie. Naar beste schatting is in $20-30 \%$ van voorkomende gevallen het stotteren chronisch. Therapie op jonge leeftijd (early intervention) kan het herstel bevorderen (SonnevilleKoedoot e.a., 2015). Een overzicht over het vóórkomen (8\% op kinderleeftijd; Yairi \& Ambrose, 2013) en hoe therapie op peuterleeftijd verschilt van therapie bij volwassenen is te vinden in de Nederlandse richtlijn Stotteren bij kinderen, adolescenten en volwassenen (NVLF, 2020). Zie ook in dit tijdschrift (Oonk \& Busser, 2022).

Bij de bespreking van het verschijnsel stotteren in de behandelkamer heeft de logopedist een begrijpelijk, actueel verklaringsmodel nodig. Werkmodellen beogen een overzichtelijke, benaderbare verbeelding van de actuele wetenschappelijke inzichten te geven. Een werkmodel is noodzakelijkerwijs kort en kan niet alle details weergeven. In de logopediestottertherapie (en wel voornamelijk in de Nederlandstalige omgeving) werd en wordt nog steeds vaak het klinisch werkmodel van Bertens gebruikt en onderwezen (Bertens, 1994; 2017). In dit model wordt verondersteld dat een primaire neuromusculaire timingsstoornis ten grondslag ligt aan ontwikkelingsstotteren. Dit model was destijds een begrijpelijke poging om stotteren uit de diagnosegroep van psychosociale stoornissen te halen. Zo bleken bijvoorbeeld primaire angststoornissen of een slechte invloed van opvoeding geen kenmerken te zijn van personen die stotteren (PDS). De aanname over een basale neuromusculaire timingsstoornis sloot aan bij het invloedrijke gedachtengoed van één van de pioniers van stottertherapie, Van Riper (1990), maar wetenschappelijk onderzoek van de laatste tien jaar heeft aannemelijk gemaakt dat zijn hypothese revisie behoeft.

Dit artikel is de voorbereiding van de presentatie van een actueel werkmodel stotteren. Hier worden kort recente inzichten met betrekking tot diverse aspecten van het ontstaan en de ontwikkeling van stotteren besproken, als ook hoe deze inzichten hun vorm hebben gekregen in een aantal recente, gepubliceerde wetenschappelijke modellen. De algemene opbouw is niet zo zeer een uitgebreide review van de literatuur, maar meer een tutorial als onderbouwing voor het door ons voorgestelde model dat in een bijgaande publicatie verder zal besproken worden (zie Oonk e.a., 2022). 


\section{Beschouwing}

Wat is stotteren? Een fenomenologische beschrijving

Het meest voorkomende stotteren ontstaat op jonge leeftijd - bijna altijd in de periode 2-5 jaar- tijdens de vroege ontwikkeling en wordt daarom officieel 'ontwikkelingsstotteren' genoemd. Kortheidshalve gebruiken we in dit artikel daar de term 'stotteren' voor. Het is herkenbaar aan herhalingen en onderbrekingen van het vloeiende spraakritme die langere tijd aanwezig blijven en die buiten de normale spraak- en taalvariatie voor de leeftijd vallen. Ernstig stotteren kan de verstaanbaarheid verminderen en kan de communicatie negatief beïnvloeden. Het kan gaan om herhalingen van klanken, lettergrepen of woorden, klankverlengingen, gebroken woorden, blokkades, tremoren, opvallend vaak gebruik van stopwoorden en snelle, korte explosieve spraak (WHO definitie ICD11 6A01.1 (icd.who.int/ en)). Stotteren kan spreekangst veroorzaken en beperkingen geven in de effectieve communicatie, sociale participatie, schoolresultaten of werkpresentaties. Ontwikkelingsstotteren wordt onderscheiden van spraakontwikkelingsdyspraxie, waarbij de motorische planning van spraakklanken en -lettergrepen is aangedaan, en van een aangeboren dysarthrie, waarbij de spraakmotorische uitvoering is verstoord. Ontwikkelingsstotteren kan niet worden toegeschreven aan een zintuiglijke beperking (bijvoorbeeld gehoorstoornis), aan nietvloeiende spraak samenhangend met neurologisch letsel (bijvoorbeeld ziekte van Parkinson, een beroerte, tumor, trauma) of een andere somatische aandoening, en kan niet beter worden verklaard door een andere psychische stoornis (bijvoorbeeld angststoornis) (DSM $5,2016)$.

\section{Genetische aanleg (zie ook box 1)}

$\mathrm{Al}$ eeuwenlang wordt de genetische invloed op overeenkomsten tussen ouders en kinderen bestudeerd, zowel van lichamelijke factoren zoals kleur van ogen, alsook van meer psychische factoren, zoals persoonlijkheidskenmerken. Hierbij wordt onderscheid gemaakt tussen monogene en complexe erfelijke eigenschappen. Monogene eigenschappen worden grotendeels door één enkel gen bepaald, zoals het hebben van sproetjes, lactose-intolerantie of de ziekte van Huntington (Bastiaens e.a., 2001; Obermayer-Pietsch e.a., 2009; Myers, 2004). Complexe eigenschappen daarentegen, worden in hun uitingsvorm beïnvloed door een combinatie van vele genetische factoren alsook niet-genetische omgevingsfactoren.

Studies met tweelingen (eeneiig versus twee-eiig) of na adoptie zijn krachtige methoden bij het bepalen van de mate van genetische invloed (de erfelijkheid) bij complexe eigenschappen. Bij stotteren zijn diverse grote studies uitgevoerd met tweelingen (soms tot 20.000 individuen) en deze resulteerden in een gevonden erfelijkheid van maar liefst $42-84 \%$ (Dworzynski e.a., 2007; Van Beijsterveldt e.a. 2010 en Fagnani e.a. 2011). Dit is iets lager dan de erfelijkheid van bijvoorbeeld autisme (64-91\%) (Tick e.a., 2015) en lichaamslengte (89-93\%) (Silventoinen e.a., 2003), en hoger dan de erfelijkheid van bijvoorbeeld slapeloosheid (32-44\%) (Madrid-Valero e.a., 2021). Waarschijnlijk is stotteren in de meeste gevallen een complexe eigenschap. Hierbij beïnvloeden duizenden genetische factoren de kans om stotteren te ontwikkelen, elk met een heel klein effect. Welke genetische factoren dat 
zijn, is nu onderwerp van grote studies waar ook Nederlandse onderzoekers aan bijdragen (geneticavanstotteren.nl; geneticsofstutteringstudy.org.au).

Box 1: Toelichting op het tot uiting komen van genetische eigenschappen in samenhang met de omgeving en individuele factoren

Genetische technieken hebben in de laatste jaren grote ontwikkelingen doorgemaakt. Aanvankelijk functioneel (het selecteren van verschillende typen erwten door Mendel), daarna ook microscopisch (zo konden gebieden op chromosomen aangetoond worden, waarbij de relatieve afstand (linkage, in de tekst gebruikt) tussen twee verschillende genen kon worden bepaald, en nu vooral moleculair. Een cel heeft een diameter van $30 \mathrm{~nm}$ (ongeveer 3000 keer kleiner dan de diameter van een haar), en daarin zit ingenieus opgekruld 2 m DNA. Ongeveer $1 \%$ van dat ellenlange DNA bestaat uit genen, in de mens ongeveer 20.000.

Genen bevatten de code voor eiwitten: grote moleculen die in het lichaam belangrijke functies vervullen, zoals enzymen die chemische reacties mogelijk maken, signaalmoleculen en hun receptoren die berichten overbrengen in een cel en tussen cellen, en bouwstenen die structuur geven in en buiten de cel. Monogene eigenschappen, veroorzaakt door een verandering in een enkel gen, komen voor. Een voorbeeld van een monogene eigenschap is het hebben van sproetjes (Bastiaens e.a., 2001); een ander - dramatisch - voorbeeld van een monogene ziekte is een bepaalde vorm van hemofilie (bloederziekte), waar het Russische Tsarendom aan ten gronde is gegaan. Echter, de meeste eigenschappen (ook ziekten) zijn multifactorieel. Dit geldt zowel de betrokkenheid van vele diverse genen als ook de invloed van omgevingsfactoren. Een voorbeeld van een multifactoriële aandoening uit de immunologie: Bij allergisch astma kunnen abnormale afweerstoffen tegen normale antigenen het ziekteproces veroorzaken en/of verergeren. De neiging om deze abnormale (meestal zgn. IgE) antistoffen in sterkere mate te maken is genetisch bepaald (Mukherjee \& Zhan , 2011; Bottema at al, 2010). Of deze afweerstoffen worden gemaakt, kan afhangen van blootstelling aan een van deze antigenen en zelfs in welk seizoen het kind (ja meestal begint het op kinderleeftijd) geboren is (Susanto e.a., 2017). En er zijn in de latere ontwikkeling van astma nog veel meer genen bij betrokken dan alleen de genoemde voor de synthese van IgE. Bij astma zijn kennelijk aangeboren factoren, omgevingsinvloeden en persoonlijk bepaalde modulerende factoren belangrijk; het is een duidelijk voorbeeld van de invloed van regulatie en terugkoppeling op al aanwezige genetisch bepaalde factoren. In de meeste modellen die later in dit artikel worden gepresenteerd zijn deze drie groepen factoren opgenomen.

De identificatie van families met veel familieleden die stotteren heeft geleid tot een zoektocht naar de betrokken genen. In elk van deze families lijkt namelijk een specifiek gen ten grondslag te liggen aan het stotteren (Kang e.a., 2010). Middels klassieke linkage studies zijn er momenteel meer dan twintig gebieden op diverse chromosomen die een suggestieve dan wel significante associatie hebben met stotteren (Frigerio-Domingues \& Drayna, 2017), en 
dus mogelijk de oorzaak van het stotteren in de familie bevatten. In nader beschreven families zijn twee verschillende genen gevonden (GNPTAB en AP4E1) die het stotteren in deze families wellicht kunnen verklaren (Kang e.a., 2010 en Raza e.a., 2015). Bij verder onderzoek naar twee andere genen (GNPTG en NAGPA) met een zelfde soort biologische functie als GNPTAB zijn in meerdere PDS genetische varianten gevonden die suggereren dat ook deze genen soms monogeen kunnen bijdragen aan het ontstaan van stotteren (Fedyna, Drayna \& Kang, 2011; Raza e.a., 2016). De kwantitatieve bijdrage van de (weinige) tot nu toe geïdentificeerde genen als verklaring voor het stotteren bij 'alle' PDS is echter niet hoog. Dit kan minstens twee redenen hebben: de zoektocht naar de betrokken genen (in het geval van 'monogeen' stotteren) op de andere gebieden uit de linkage studies is nog niet afgerond en vooral: stotteren heeft in de meeste PDS waarschijnlijk een genetisch complexe basis.

Naast de aangehaalde tweelingstudies is er ook op een andere manier bewijs gevonden voor een rol van genetische factoren en de omgeving bij het ontwikkelen van stotteren. De studie van Poulos en Webster (1991) is informatief, al is de zelfrapportage van de studie een beperking: zij vonden dat bij 66\% van hun participanten (adolescenten en volwassenen) stotteren in de familie voorkwam. Dat betekent niet dat bij de overige $34 \%$ geen genetische factoren betrokken waren: er zijn vele (honderden of duizenden) genetische factoren betrokken bij complexe stoornissen, en ook mensen die niet stotteren of geen familieleden hebben die stotteren kunnen vele hiervan bij zich dragen. Maar mogelijk is de rol van genetica kleiner in de groep zonder familieleden die stotteren. De onderzoekers keken verder naar diverse, potentieel relevante voorvallen vroeg in het leven (een zeer gevarieerde lijst) en vonden dat bij deze groep van $66 \%$ in zo'n $2,5 \%$ zulke gebeurtenissen (bv prematuriteit, auto-ongeval) waren voorgekomen. Echter, in de minderheid zonder gerapporteerd stotteren in de familie (dus de andere $34 \%$ van het totaal) werden dergelijk potentieel relevante gebeurtenissen gemeld in $37 \%$ van die gevallen. Deze studie suggereert dat de omgeving een grotere rol speelt bij het ontwikkelen van stotteren als er minder genetische factoren betrokken zijn. De lijst is zeer divers en ook latere studies leverden niet veel meer specifieke data. De auteurs hechten ook groot belang aan de $63 \%$ van deze subgroep waar dergelijk potentieel relevante gebeurtenissen niet werden gerapporteerd. Waarschijnlijk spelen in deze subgroep ook (minder duidelijke) omgevingsfactoren en genetische factoren een rol, of in sommige gevallen zelfs een nieuwe mutatie. Ook dit wordt nader onderzocht, zie o.a. geneticavanstotteren.nl.

Gebaseerd op de resultaten van het genetisch onderzoek hebben onderzoekers nu ook een muismodel gemaakt op basis van een van de eerst gevonden genen: GNPTAB (Barnes e.a., 2016, Han e.a., 2019). Deze zogenaamde transgene muizen, die een genetische variant in het GNPTAB gen dragen die gelinkt is aan verondersteld monogeen stotteren, vertoonden als pasgeboren pup een ander piepgedrag dan normale muizen. Dit onderwerp is verder uitgewerkt door Frigerio-Domingues, Han en Drayna. (2021; zie List of Research Notes (theifa.org)). In vergelijking tot dergelijke studies naar monogene oorzaken van stotteren, staat het genetisch onderzoek naar een complexe oorzaak van stotteren nog in de kinderschoenen.

Het feit dat stotteren deels erfelijk is, betekent niet dat stotteren onvermijdelijk is. Ten eerste gaan niet alle kinderen van ouders die stotteren zelf ook stotteren. Bovendien heeft 
een eerste studie naar de effecten van kortdurende intensieve therapie bij volwassen PDS met een genetische variant in één van de vier nu geïmpliceerde genen aangetoond dat ook zij (gemeten als objectieve stotterfrequentie) goed kunnen reageren op spraakveranderings therapie; het positieve effect van deze therapie op de subjectieve stotterernst was bij de dragers overigens minder groot (Frigerio Domingues e.a., 2019). Verder onderzoek is hier nodig; zo is bijvoorbeeld nog niet duidelijk of er genetische verschillen zijn tussen persistent en hersteld stotteren. Ook is nog niet bekend of de hierboven vermelde geringe invloed van genetische achtergrond op het welslagen van therapie bij volwassenen (Frigerio Domingues e.a., 2019) ook geldt bij vroege interventie.

\section{Neurologische aspecten (zie ook box 2)}

Moderne structureel-anatomische en functionele beeldvorming van hersenen heeft inmiddels een aantal verschillen tussen PDS (zowel bij volwassenen en kinderen ) en personen zonder stotteren aangetoond (Etchell e.a., 2017). In structurele studies leek het in eerste instantie te gaan om een beperkt aantal afwijkingen in specifieke spraak- en taalgebieden van grijze en witte stof (Beal e.a., 2013). In functionele studies werd duidelijk dat er bij PDS minder interacties zijn tussen de auditieve en motorische cortex, alsook tussen de spraakmotorische cortices van de beide hersenhelften, dan bij personen die niet stotteren (Chang $\&$ Zhu, 2013). Dit was zowel het geval in rust, als bij spreken. Minder interacties tussen relevante hersengebieden kunnen duiden op een minder efficiënte, neurologische aansturing van spraakmotorische processen. Of al deze structurele en functionele verschillen nu de oorzaak of (deels compensatoire) gevolgen van stotteren zijn, of beide, is op dit ogenblik nog niet duidelijk. Bij kinderen die ooit gestotterd hebben, bleken specifieke gebieden bestaande uit zenuwcellen die belangrijk zijn voor de aansturing van spraak kleiner te zijn dan bij kinderen die niet stotteren (Chang e.a., 2008, Foundas e.a., 2013, Beal e.a., 2013, Koenraads e.a., 2019). Echter, degenen die herstelden van stotteren lijken hiervoor te kunnen compenseren (Garnett e.a., 2018; Koenraads e.a., 2020). Chow \& Chang (2017) vonden bij kinderen die stotterden gemiddeld wel een afwijkend senso-motorisch netwerk, maar de spreiding was groot. Toch maakte het afwijkende netwerk subtiel onderscheid tussen kinderen die herstelden van stotteren en kinderen die bleven stotteren (Chow \& Chang, 2017).

Recent onderzoek heeft bij PDS ook de eerste aanwijzingen gegeven dat er binnen het individu verschillen zijn tussen de onderliggende neurologische processen geassocieerd met gestotterde dan wel vloeiend-gesproken woorden (Mersov, e.a., 2018).

In de hierboven genoemde studie met muismodellen voor monogeen stotteren vonden de onderzoekers in hun transgene muizen (zie in hoofdje Genetische aanleg hierboven) een specifiek verlaagde aankleuring voor astrocyten (een type cel in de hersenen dat de hersencellen ondersteunt) en wel vooral in het corpus callosum de zenuwbaan die beide hersenhelften met elkaar verbindt (Han e.a., 2019). Een andere studie kon een link vinden tussen het aan stotteren gerelateerde corticale netwerk van normale volwassenen en kinderen en de concentratie GNPTG (een van vier genen die gelinkt is aan stotteren, zie boven) (BenitoAragón e.a., 2020). Deze recente ontwikkelingen zijn nog moeilijk te duiden, maar het be- 
lang van deze bevindingen (de link tussen de genetica en neurologie bij stotteren) wordt elders toegelicht (Chow \& Chang, 2021; zie List of Research Notes (theifa.org)). Stotteren bij kinderen en volwassenen is geassocieerd met bepaalde verschillen in spraakmotorische, structurele en functionele hersengebieden, al is de precieze oorzakelijke samenhang nog niet bekend.

\section{Motorische aspecten}

Zoals hierboven reeds genoemd, is in de jaren 80 de hypothese gelanceerd dat stotteren gebaseerd is op een neuromusculaire timingsstoornis (Van Riper, 1990). Dat idee was toen zeer welkom omdat een neurofysiologische in plaats van een psychologische oorzaak meer relevant leek bij stotteren. In dit kader is er onderzocht of de veronderstelde motorische stoornissen beperkt zijn tot spraak of ook in andere motorische activiteiten optreden. Zo werd er bv. onderzoek gedaan naar asynchroon kunnen handenklappen bij kinderen die wel en bij kinderen die niet stotteren. Aanvankelijke resultaten gaven bij een deel van de stotterende kinderen een grotere variabiliteit van het interval tussen het handklappen aan (Olander, Smith \& Zelaznik, 2010). Echter later heeft dezelfde groep na grotere studies (Hilger, Zelaznik \& Smith 2016) deze conclusie teruggetrokken: er bleek altijd sprake van een grote overlap tussen stotterende en niet-stotterende kinderen. Bovendien, ook als er aanvankelijk meer variabiliteit van het handenklappen gevonden werd bij kinderen die stotteren, bleek dit na een korte oefening niet meer op te treden, dus niet basaal te zijn (Korzeczek e.a., 2020). Of een motorische stoornis bij stotteren beperkt blijft tot spraakmotoriek blijft op dit moment nog een open vraag (Kim e.a., 2020, Sares e.a.., 2019, Daliri e.a.., 2014).

Dit laat onverlet dat bij specifiek spraakgerelateerde taken bij volwassenen en bij kinderen die stotteren in diverse studies een grotere variabiliteit gevonden is (Lenoci \& Ricci, 2018; Kleinow \& Smith, 2000; Usler, Smith \& Weber, 2017). Smith \& Kleinow (2000) vonden subtiele verschillen in kinematische parameters tussen volwassenen die stotteren en controle personen die niet stotteren. De auteurs interpreteren deze als duidend op een grotere gevoeligheid voor spraakmotorische uitval wanneer de prestatie-eisen toenemen. Dezelfde auteurs vonden hiervoor bevestiging in een studie naar het effect van zinslengte en -complexiteit bij volwassenen op de spraakmotorische stabiliteit (Kleinow \& Smith, 2000). Ook bij stotterende kinderen op de schoolleeftijd werden uitkomsten gevonden die duiden op een kwetsbare spraakmotorische stabiliteit. Langere zinnen werden (spraakmotorisch) variabeler uitgesproken, langere en complexere zinnen werden minder precies uitgesproken en er werd vaker op gestotterd (Usler \& Walsh, 2018). Echter, ook hierbij werd steeds een overlap gevonden tussen de groepen die wel stotteren en die niet stotteren. Dit roept de vraag op of er misschien eerder sprake is van een zwakkere of sterkere vaardigheid dan van een stoornis ja dan nee. 


\section{Box 2: Toelichting op Neurologie}

Spraakproductie is een van de meest complexe, motorische processen van het menselijk brein. Om spraak te produceren zijn verschillende hersengebieden en zo'n 75-tal spieren tegelijkertijd betrokken. De spraakproductie wordt in de loop van de kinderleeftijd steeds beter georganiseerd omdat de hersenen zich continu subtiel aanpassen. Door deze aanpassingen en betere samenwerking in en tussen de twee hersenhelften zullen kinderen steeds vloeiender spreken. Bij een overgroot gedeelte van de mensheid (maar ook beïnvloed door bv rechts- of linkshandigheid) is de linkerhersenhelft dominant voor taal en spraak (Knecht e.a., 2000). Onderzoek naar kinderen en volwassenen die stotteren richt zich op de structuur en functie van diverse hersengebieden en op de asymmetrie tussen de linker- en rechterhemisfeer.

De hersenen zijn opgebouwd uit grijze en witte stof. De hersenschors, ofwel cortex cerebri, bestaat uit grijze stof en is samengesteld uit neuronen en dendrieten. Deze hersengebieden zorgen voor waarnemingen en interpretatie van zintuigelijke prikkels van het lichaam en initiëren onder andere bewegingsopdrachten en voeren deze uit. De witte stof bestaat vooral uit axonen met isolerende myeline (dat zorgt voor de witte kleur), die de hersengebieden verbinden. Door deze isolatie van myeline kan de prikkeloverdracht tussen hersengebieden en tussen hemisferen razendsnel plaatsvinden. Verschillende wittestofbanen vormen samen een neurologisch netwerk (of neuraal circuit). Bepaalde neurale circuits in de hersenen organiseren de bewegingen en sturen spraak motorisch aan door het plannen, verwerken, transformeren en overdragen van informatie.

Diverse moderne, beeldvormende technieken worden de laatste jaren wereldwijd gebruikt voor hersenonderzoek. Structurele beeldvorming richt zich op het analyseren van de hersenstructuur, ofwel de anatomische (structurele) component. Volumebased en voxel-based Magnetic Resonance Imaging (MRI) geven informatie over de vorm (bijvoorbeeld volume, dikte, oppervlakte) van specifieke grijze hersenstructuren. Diffusion Tensor Imaging (DTI) brengt structurele informatie in kaart over de richting en sterkte van wittestofverbindingen, ofwel het diffusiepatroon van neurale circuits. DTI laat zien wat de kwaliteit is van wittestofbanen en welke hersengebieden met elkaar communiceren. Functionele beeldvorming, daarentegen, richt zich op de activiteit van hersengebieden en de actieve connectie tussen hersengebieden en maakt onder andere gebruik van Functional MRI (fMRI) en magnetoencephalography (MEG) en functional near infrared spectroscopy (fNIRS). Hiernaast zijn er nog tal van andere technieken voor het analyseren van de hersenstructuur,- functie en ontwikkeling.

De motorische cortex (verantwoordelijk voor de uitvoering van bewegingen) en de auditieve cortex (de gehoorschors) gaan beter samenwerken naarmate de hersenen zich verder rijpen en een kind meer ervaring krijgt met spreken. Er wordt vermoed dat feedback ervoor zorgt dat na verloop van tijd specifieke hersenstructuren worden geactiveerd en efficiënter samenwerken, waardoor kinderen door de jaren heen vloeiender gaan spreken. Afhankelijk van het (onbewuste gemak) van het spreken is dit een positieve terugkoppeling (stimulatie van de hersenen om de spraak op dezelfde manier uit te voeren) of een negatieve terugkoppeling (stimulatie van de hersenen om de spraak te verbeteren; Soo-Eun Chang, aangehaald door Koenraads en Franken, 2018). 


\section{Linguïstische aspecten}

Stotteren ontstaat in de periode dat de taal zich explosief ontwikkelt: het jonge kind leert veel nieuwe woorden en gaat steeds langere en complexere zinnen gebruiken. Over de samenhang tussen stotteren en taalontwikkeling bestaat geen consensus. Diverse studies vonden dat jonge kinderen die stotterden iets zwakkere taalvaardigheden hadden dan kinderen die niet-stotterden, zowel in de receptieve als de productieve taal (zie voor een review: Ntourou, Conture \& Lipsey, 2011). Echter, andere studies vonden een normale spreiding van taalvaardigheid bij jonge kinderen die stotterden (o.a. Watts e.a., 2015; 2017). Enkele studies vonden zelfs eerder aanwijzingen voor bovengemiddelde taalvaardigheid kort na het ontstaan van stotteren (Watkins e.a., 1999; Reilly e.a., 2013). Daarnaast is er een lijn van onderzoek die heeft aangetoond dat kinderen die stotteren niet noodzakelijkerwijs taalstoornissen hebben, maar eerder subtiele verschillen in het verwerken van bepaalde taalkundige aspecten, zoals de semantiek (Gerwin \& Weber, 2020).

Minstens zo belangrijk voor de vroege behandeling van stotteren is kennis over de samenhang tussen stotteren en (spraak-)taalvaardigheid bij kinderen die zullen blijven stotteren. Een zeer recente meta-analyse (Singer e.a., 2020) concludeert op basis van het combineren van de uitkomsten van elf studies dat zwakkere correcte klankproductie, en lagere receptieve en expressieve taalvaardigheid op jonge leeftijd significant geassocieerd zijn met blijvend stotteren. Een associatie wijst niet noodzakelijkerwijze op een oorzaak. Het lijkt echter aannemelijk dat een ernstige beperking in de spraakmotorische coördinatie reeds vanaf de zeer vroege ontwikkeling de spraak- en taalontwikkeling belemmert, zoals dat het geval is bij kinderen met een spraakontwikkelingsdyspraxie.

\section{Temperament en persoonlijkheid}

Temperament verwijst naar de wijze waarop een persoon in het algemeen reageert op zijn omgeving en hoe hij/zij ermee inter-ageert. Temperament is deels genetisch bepaald. Temperamentstrekken komen van individu tot individu door leerprocessen anders tot expressie en dan noemen we het resultaat persoonlijkheidskenmerken (Kefalianos e.a., 2017). Onderzoek naar de persoonlijkheidsstructuur van PDS vindt geen aanwijzingen voor een onderliggend neurotische - of persoonlijkheidsstoornis als oorzaak voor stotteren. De eventuele emotionele problemen van PDS lijken eerder een reactie te zijn op het stotteren dan een oorzaak hiervan (Alm, 2014), maar zij zijn vaak wel een belangrijk element van de conditie stotteren en de verdere ontwikkeling hiervan. In onderzoek naar temperament bij kinderen die stotteren is gezocht naar bepaalde kenmerken van het temperament die geassocieerd kunnen worden met het ontstaan van stotteren, met specifieke stottersymptomen en het verloop van stotteren (herstel of persisteren). Verschillende studies laten tegenstrijdige resultaten zien, wat het moeilijk maakt om duidelijke conclusies te trekken i.v.m. specifieke temperamentkenmerken. Er is gevonden dat kinderen die stotteren in vergelijking met een controlegroep van kinderen die niet stotteren zich minder goed kunnen aanpassen, een kortere aandachtspan hebben en meer negatieve gevoelens hebben (Eggers, De Nil \& Van den Bergh, 2010). In een Australisch bevolkingsonderzoek vond men weinig bewijs voor een verband tussen het ontstaan van stotteren en temperamentstrekken (Kefalianos e.a., 2014). Evenmin werden in deze studie associaties gevonden tussen temperamentstrekken en stot- 
terernst op de leeftijd van vier jaar en temperamentstrekken en type stottergedragingen op de leeftijd van zes jaar (Kefalianos e.a., 2017). Echter, in een Rotterdams bevolkingsonderzoek werd wel een significant verband gevonden tussen gaan stotteren enerzijds en gedragsproblemen en temperamentskenmerken anderzijds op de leeftijd van 5 tot 9 jaar (Koenraads e.a., geaccepteerd voor publicatie). Eveneens is een significant verband gevonden tussen een negatief affectief temperament (negatieve reactiviteit) en persisteren van stotteren (Ambrose e.a., 2015). Ook Koenraads e.a., (2021) vonden significante verbanden tussen persisterend stotteren en een hogere emotionele reactiviteit en lagere zelfregulatie op de leeftijden van zes maanden, vijf jaar en negen jaar.

\section{Auditieve feedback}

Problemen in de auditieve feedback, of het gebruik ervan, worden al zo'n halve eeuw als een mogelijke (mede)oorzaak van stotteren beschouwd. Wat ouder onderzoek heeft aangetoond dat bij een subgroep van PDS het planum temporale (PT), een gebied in de auditieve cortex, anatomisch atypisch is (Foundas, 2010). Recent beeldvormend hersenonderzoek naar spraakperceptie vond dat stotteren geassocieerd was met afwijkende corticale responsen tijdens de spraakperceptie (Halag-Milo e.a., 2016). Beal en collega's onderzochten of kinderen die stotteren beperkt zijn in hun vermogen om auditieve feedback optimaal te gebruiken (Beal, e.a. 2011). In een taak waarbij (school)kinderen klinkers produceerden, hadden kinderen die stotterden bilateraal een vertraagde auditieve corticale verwerking (vertraagde M50 pieklatentie) van deze klinkers vergeleken met kinderen die niet stotterden. De auteurs concludeerden dat stotterende kinderen auditieve informatie minder goed kunnen integreren met spraakmotorische processen. Deze bevinding, in combinatie met hun eerdere bevinding dat volwassenen die licht stotterden tijdens klinkerproductie sneller de rechter auditieve cortex inschakelden (rechts sneller dan links) dan ernstig stotterende volwassenen, vinden de auteurs een ondersteuning voor het idee dat de toename van corticale auditieve verwerking in de rechter hemisfeer bij volwassenen die stotteren tijdens klinkerproductie compenserend van aard is, in plaats van een aangeboren eigenschap. Een serie onderzoeken door Max en collega's (voor een overzicht, zie Max \& Daliri, 2019) heeft aangetoond dat volwassenen die vloeiend spreken hun auditieve input iets aanpassen op basis van de geplande spraak vooraleer ze beginnen te spreken, een effect dat niet terug te vinden was bij volwassenen die stotteren. De onderzoekers speculeerden dat de gevonden groepsverschillen kunnen wijzen op een inefficiëntie in het integreren van auditieve feedback tijdens spraakmotorische planning en uitvoering. Echter, het effect zou ook verband kunnen houden met een preoccupatie met vloeiend spreken in de groep van volwassenen die stotteren: men past auditief alleen iets aan als de spraak er vloeiender van wordt. Deze laatste verklaring past ook bij de interessante bevinding van deze onderzoekers dat het gevonden verschil tussen volwassenen die wel en niet stotteren, níet aanwezig was tijdens vertraagde auditieve feedback (DAF). In deze conditie is de spraak van mensen die stotteren doorgaans (wat trager en) vloeiender. Max \& Daliri (2019) menen dat dit (mede) komt door een efficiëntere integratie van de auditieve feedback bij personen die stotteren tijdens DAF. Een andere verklaring is dat DAF de proprioceptieve feedback versterkt wordt, waardoor de stabiliteit van het spraakmotorische systeem wordt versterkt. 


\section{Recente modellen}

Op basis van bovenstaande recente inzichten, hebben diverse wetenschappers verschillende modellen ontwikkeld. Modellen zijn gebaseerd op interpretaties en versimpelingen van bestaande literatuur. Ze beogen dus niet de totale kennis weer te geven, en zijn ook continu aan aanpassing onderhevig. Alleen een beperkt aantal wordt hier genoemd: modellen die makkelijk klinisch toepasbaar zijn en die binnen de huidige bevindingen verschillende accenten benadrukken, worden genoemd.

Het Packman en Attanasio 3-factoren causale model van stottermomenten (P\&A model, Packman \& Attanasio, 2010; Packman, 2012) is het eenvoudigste, meest globale model dat hier wordt gepresenteerd (Figuur 1). Het model onderscheidt drie factoren: (1) een basaal aanwezige aandoening (een beperking in de neurologische verwerking van gesproken taal die het spraaksysteem instabiel maakt en vatbaar voor verstoring), (2) triggers inherent aan de gesproken taal die hogere motorische eisen stellen aan het spraaksysteem (een variabel klemtoonpatroon en linguïstische complexiteit ), en (3) individueel bepaalde modulerende factoren (fysiologische arousal, cognitieve resources (bronnen) en reactie op omgevingsfactoren). Conceptueel is dit model eenvoudig, goed te begrijpen en goed uit te leggen. De huidige stand van wetenschap laat toe om deze drie factoren iets uitgebreider te definiëren, en deze begrippen zijn in andere hierna volgende modellen nader uitgewerkt.

De Multifactorial Dynamic Pathway Theory van Smith en Weber (2017) (zie figuur 2) beschrijft de ontwikkeling van het stotteren binnen algemene (vnl. neurologisch gedefinieerde) aspecten in de ontwikkelingsbiologie als een interactief, dynamisch samenspel tussen verschillende ontwikkelingsfactoren zoals cognitie, taal, motoriek en genetica. Een belangrijke toevoeging ten opzichte van het model van Packman is een tijd-as, hier vooral gedurende de eerste zeven levensjaren. De specifieke interactie tussen de verschillende factoren en hoe zij het ontstaan en de verdere ontwikkeling van stotteren beïnvloeden is sterk individueel.

Ook het model van Conture e.a., (2006) heeft een component tijd in zich. Zie figuur 3. Het idee van tijd in dit model loopt niet in een beperkte periode (zoals Smith \& Weber, 2017), maar beslaat feitelijk de hele ontwikkeling van het stotteren gedurende het leven. Inzichtelijk wordt gemaakt hoe het in de peutertijd ontstane stotteren door terugkoppelingen een persisterend probleem heeft kunnen worden. Als oorzaak van stotteren worden genetische factoren genoemd die in interactie met de omgeving tot uiting komen. Uitlokkende factoren zijn aanwezige problemen met spraakplanning en planning van de taalproductie. Het gevolg hiervan kan zijn dat er stottermomenten optreden. Door ervaringen die de persoon opdoet gerelateerd aan de stottermomenten maar ook aan de emotionele reactiviteit van de betreffende persoon, kunnen de stottermomenten in stand blijven en verergeren.

Een integratie en verdere uitwerking van de verschillende initiërende en terugkoppelende factoren bij het stotteren (en nog dichter bij het stottermoment zelf) wordt gepresenteerd in het SAMI model (Speech And Monitoring Interaction) (Arenas, 2016; Van de Vorst \& Gracco, 2018) (Figuur 4).

SAMI onderscheidt twee afzonderlijke, maar nauw verbonden systemen: het spraak- 
2) Directe aanleidingen (prikkel / trigger / impuls)

Intinsieke kenmerken van gespoken taal

- variabele lettergreepbeklemtoning

- taalkundige complexiteit

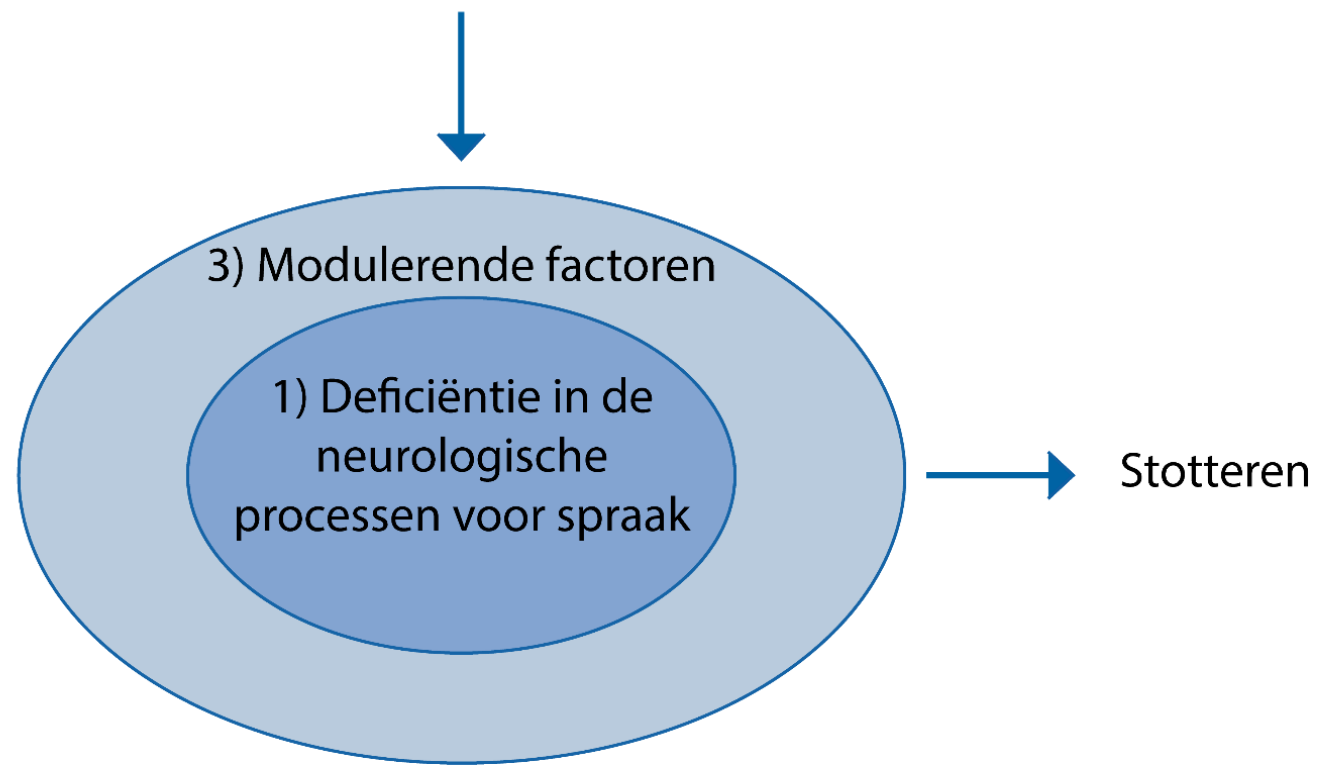

Figuur 1: Het P \& A drie factoren model van stottermomenten, naar Packman \& Attanasio (2010). Dit eenvoudige model bestaat uit drie componenten die van invloed zijn op een moment van stotteren: een (veronderstelde) neurologische, mogelijk mede genetische bepaalde deficiëntie; externe, momentane invloeden van de gesproken taal die een reactie uitlokken, zoals contrastieve klemtoon; en interne, persoonsgebonden factoren die deze reactie kunnen versterken of verzwakken, zoals het arousal. In box 1 is dit simpele model ook toegepast op het ontstaan van astma: er zijn aangeboren factoren (de neiging om abnormale antistoffen te maken), omgevingsfactoren (de allergenen moeten wel aanwezig zijn), en modulerende factoren (alles hangt van de context, bv leeftijd, af). 


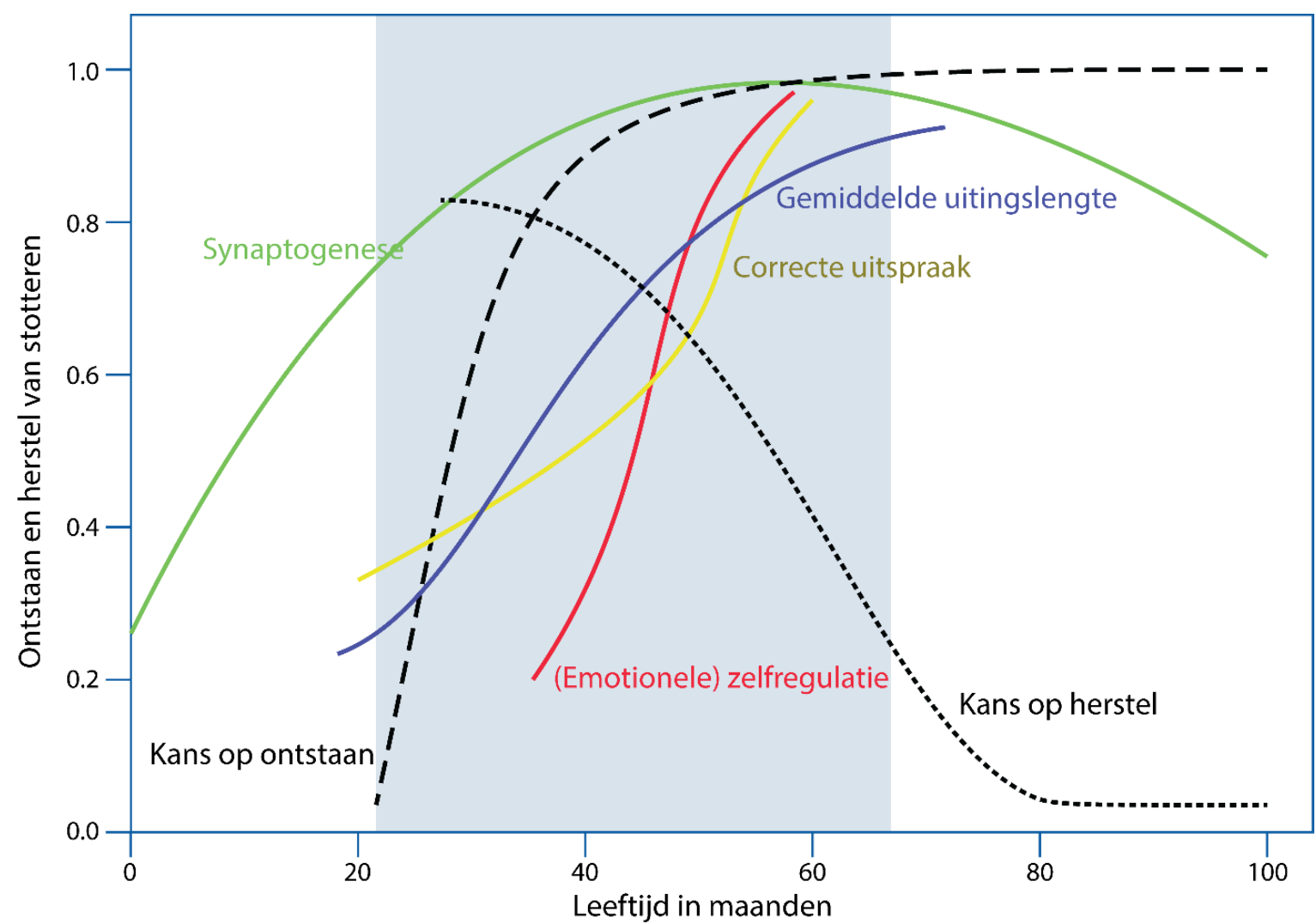

Figuur 2: De Multifactorial Dynamic Pathway Theory van Smith en Weber (2017). Tegen een achtergrond van algemeen geldende neuropsychologische ontwikkelingen, weergegeven in de doorgetrokken lijnen, wordt de kans op het ontstaan en het herstel van stotteren op kinderleeftijd weergegeven in de twee gestippelde lijnen (dik = kans op ontstaan van stotteren, dun $=$ kans op herstel van stotteren), en dit alles op een tijd-as in maanden. Het lichtblauwe vak omvat de tijdspanne waarin stotteren ontstaat en waarin zich de ontwikkeling naar herstel of persisteren voltrekt. Groen: de ontwikkeling en 'snoeien' van de verbindingen tussen hersencellen in de prefrontale cortex (het aantal synapsen; de synaptogenese). Blauw: de toename van de gemiddelde uitingslengte van het kind. Geel: toename percentage correct uitgesproken hele woorden (met de correcte spraakklanken). Rood: de ontwikkeling van het kind om zichzelf emotioneel te reguleren. 


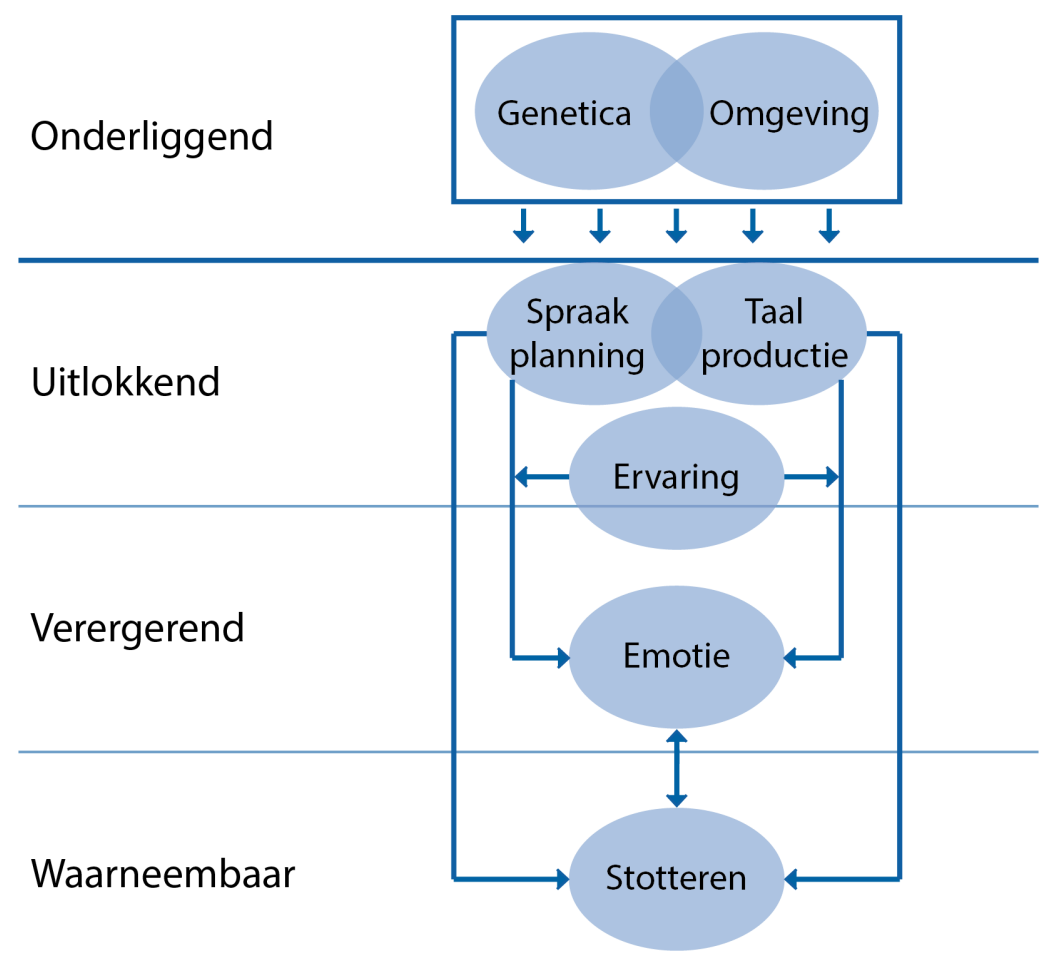

Figuur 3: Het Communication-Emotional Model of Stuttering van Conture (2006). Dit model geeft de ontwikkeling van het stotteren weer in relatie tot de tijd, die niet in een begrensd aantal maanden is bepaald (zoals figuur 2), maar de periode van het hele leven omvat. Een ander verschil met figuur 2 is dat de processen hier meer psychologisch dan neurologisch worden geduid. Echter, deze twee processen verschillen uiteindelijk niet wezenlijk van elkaar. 


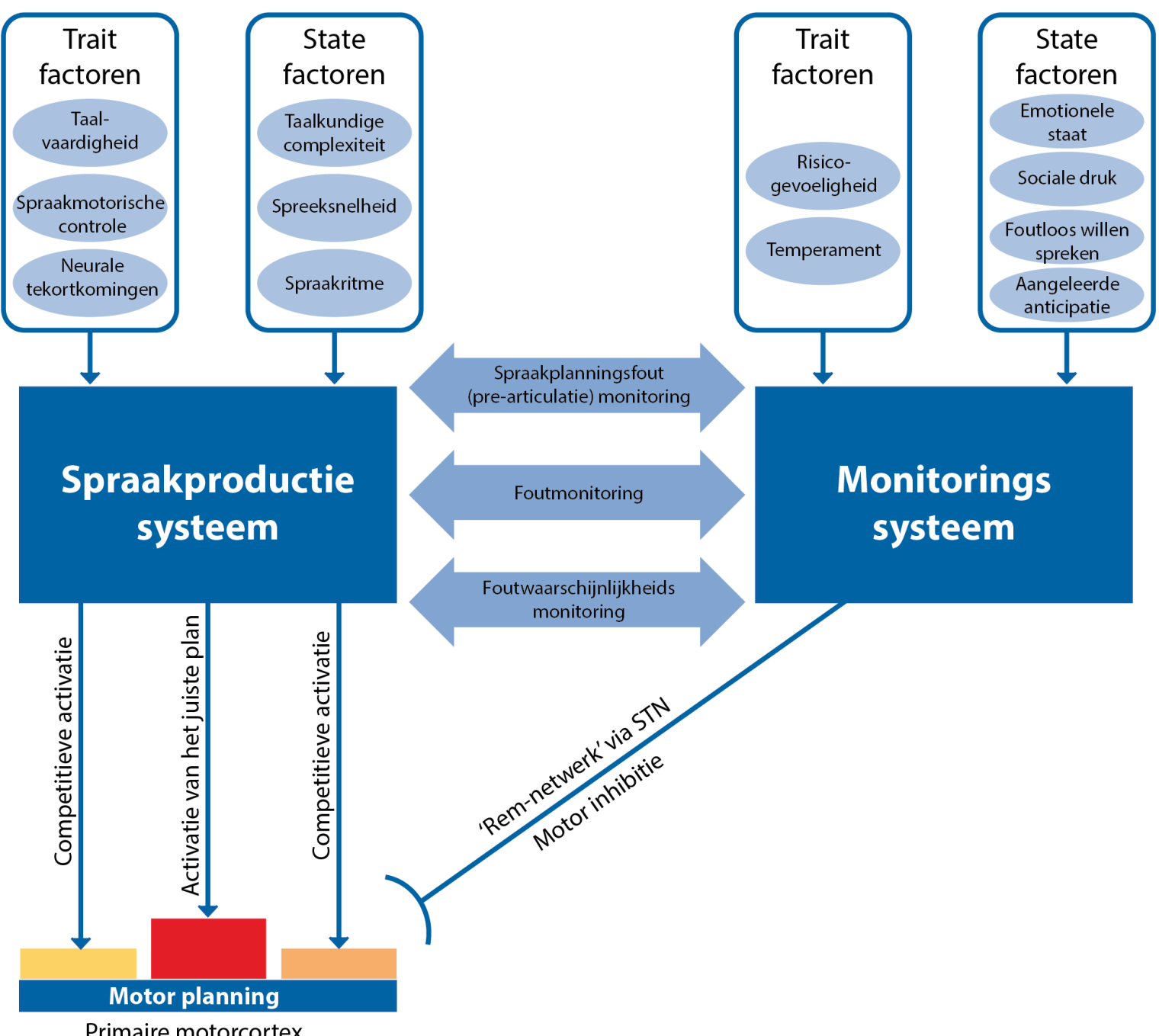

Figuur 4: Linksboven staan de trait en state factoren van het spraakproductiesysteem en rechtsboven die van het monitoringsysteem. Trait factoren zijn constant aanwezig, state factoren veranderen per situatie en context. Beide type factoren beïnvloeden zowel het spraakproductiesysteem als het monitoringsysteem. De blauwe pijlen tonen de interactie tussen beide systemen. Het gaat daarbij om het op verschillende momenten monitoren van drie typen fouten: spraakplanningsfouten (pre-articulatie), monitoren van fouten in de lopende spraak, en monitoren van verwachte fouten (anticipatie, geleerd door ervaringen).Een ingreep van monitoringsysteem op het spraakproductiesysteem geeft een verstoring (een stottermoment). Verondersteld wordt dat daarbij onder meer de nucleus subthalamicus (STN) actief is. 
productiesysteem en het systeem van monitoring (toezicht op het spraakproces) . Beide systemen beïnvloeden de efficiëntie waarmee de spraakmotorische planning wordt uitgevoerd. Het monitoringssysteem is een soort fout-detectiesysteem dat een motorische actie (bijvoorbeeld spraakproductie) kan bijstellen door deze tegen te houden zodat er meer tijd is om een foutdreiging te herstellen (Van de Vorst en Gracco, 2018). Overactiviteit van het monitoringsysteem zal de kans op stotteren vergroten. Een verklaring waarom stotteren van moment tot moment kan verschillen wordt gegeven middels de zogeheten trait en state factoren. Trait factoren zijn relatief constant aanwezig en beïnvloeden daardoor ook op een vrij constante wijze het spraakproductiesysteem en het monitoringsysteem. Voorbeelden hiervan zijn de spraakmotorische vaardigheid en het temperament van een persoon. Iemand met een risicomijdend temperament zal het monitoringsysteem sterker activeren dan iemand die dat niet heeft. State factoren daarentegen zijn context gebonden. Zo kan de linguïstische complexiteit van de boodschap als state factor (niet constant op dezelfde manier aanwezig) het spraakproductiesysteem beïnvloeden. De sociale context van de spreeksituatie en ook de anticipatie op het stotteren door de persoon zelf zijn andere voorbeelden van state factoren die het monitoringsysteem extra kunnen activeren. Een hyperactief monitoringsysteem, zoals bijvoorbeeld door veel focus op niet-stotterend spreken, beïnvloedt de efficiëntie van de spraakmotorische planning en de vloeiendheid van de spraak omdat het motorische commando's afremt. In hoeverre een overactief monitoringsysteem ontstaat door het stotteren of dat dit een aanlegfactor is, is niet duidelijk.

Bovenstaande modellen beogen een makkelijk overzicht te geven van de vele processen, zowel bij de ontwikkeling als tijdens de momentane uiting van het stotteren. Het nu volgende model, het Speech Motor Skill model (Namasivayam \& Van Lieshout (2011); Van Lieshout, Hulstijn, \& Peters, 2004 ) beschrijft één, maar wellicht wel een cruciaal aspect ervan. Deze auteurs beschouwen namelijk een beperkte spraakmotorische vaardigheid als de primaire oorzaak bij iemand die stottert.

Geïnspireerd door Williamson (1998) concretiseren Namasivayam en Van Lieshout (2011) spraakmotorische vaardigheid in een kritische drempelwaarde bij de koppeling van sensorisch-proprioceptieve signalen van de spieren naar de hersenen en omgekeerd motorische signalen van de hersenen naar de spieren. Deze drempelwaarde moet op neurologisch niveau worden gesitueerd; ze is uniek voor elk individu en ligt voor elk individu vast. Afferente en efferente signalen worden tijdens een spraakbeweging continu aan elkaar gekoppeld om de stembanden en de articulatoren (lippen, tong, kaak etc.) te positioneren. Als het afferente signaal te zwak is, wordt de kritische drempelwaarde niet gehaald en worden de koppelingen in het spraakmotorische systeem instabiel. Bij teveel instabiliteit leidt het tot een interruptie van de motorische signalen [blokkade in de beweging] en een reset is nodig, dat wil zeggen: het systeem moet weer op gang worden gebracht. Als de blokkades lang genoeg duren zullen ze waarneembaar zijn als een stotter. Namasivayam en Van Lieshout (2011) betogen dat spraakmotorische vaardigheid, net als iedere andere vorm van motoriek, voor een groot deel een kwestie van (aangeboren) aanleg is en 'normaal verdeeld': sommige personen zitten aan de "hoge" kant van dit vaardigheidscontinuüm, anderen meer in het midden en weer anderen aan de "lage" kant. Personen die geregeld onvloeiend spreken vallen waarschijnlijk in de laatste groep. 


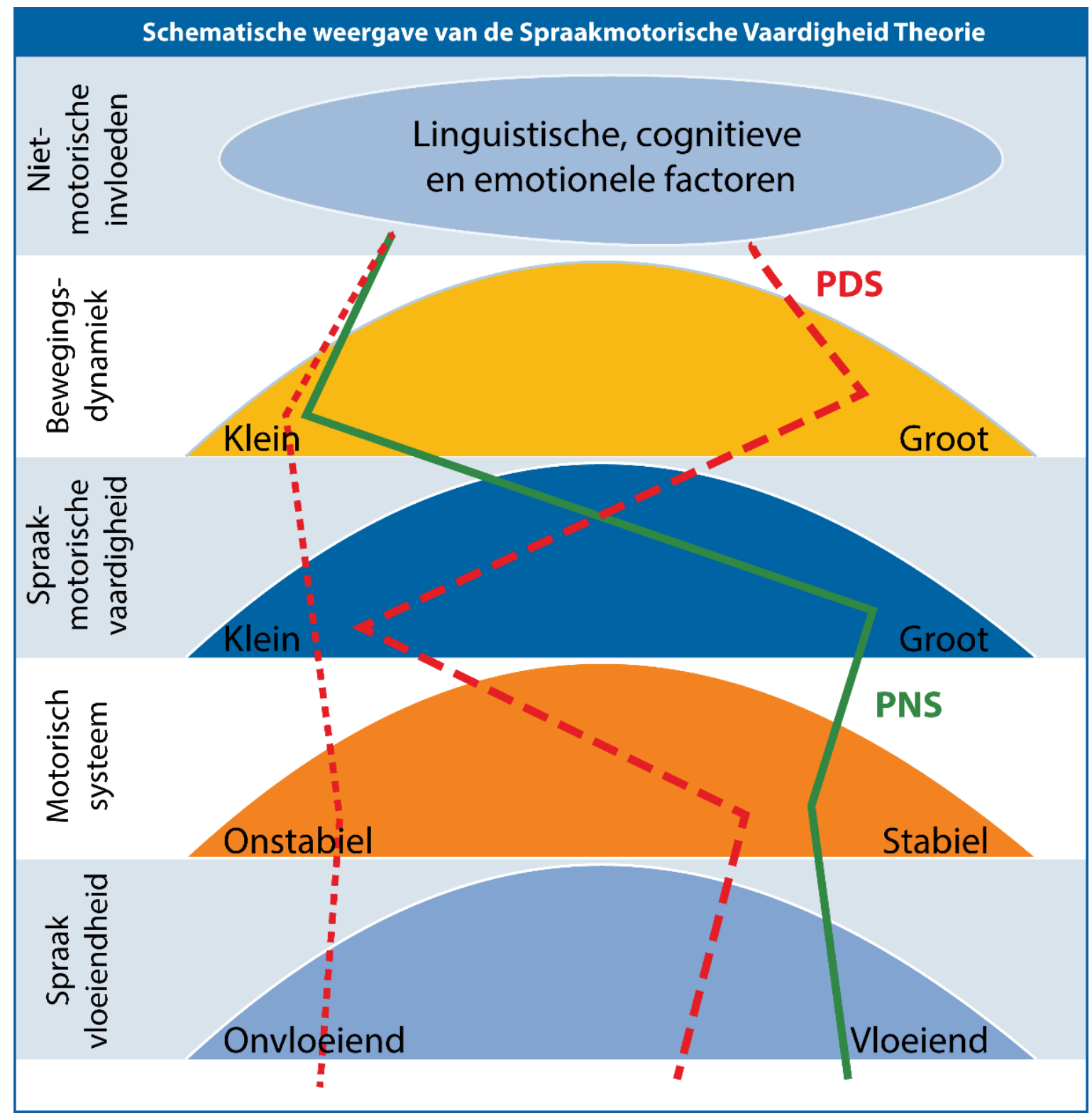

Figuur 5: Spraakmotorische Vaardigheid Theorie (naar Namasivayam \& Van Lieshout, 2011). Bovenstaande schematische weergave toont de samenhang tussen niet-motorische (linguïstische, cognitieve en emotionele) factoren en variabele motorische factoren (kleine $\longleftrightarrow$ grote bewegingsdynamiek, kleine $\longleftrightarrow$ grote spraakmotorische vaardigheid) en het effect hiervan op de stabiliteit van het motorische systeem (onstabiel $\longleftrightarrow$ stabiel) en de spraakvloeiendheid (onvloeiend $\longleftrightarrow$ vloeiend) in de Speech Motor Skill approach. PDS $=$ Personen die Stotteren, PNS = Personen die niet Stotteren. De rode lijnen hebben betrekking op PDS (beperkte spraakmotorische vaardigheid) en de groene lijn op PNS ( normaal tot goede spraakmotorische vaardigheid). De rode lijn met kleine stippels laat zien dat PDS die kleine spraakbewegingen maakt een onstabiel spraakmotorisch systeem heeft met als gevolg onvloeiende spraak. De rode lijn met grote stippels laat zien dat het spraakmotorische systeem van PDS die grote spraakbewegingen maakt veel stabieler blijft met als gevolg (bijna) vloeiende spraak. De groene lijn toont dat het spraakmotorisch systeem van PNS ook met kleine spraakbewegingen stabiel blijft met als gevolg vloeiende spraak. 
Figuur 5 illustreert hoe Namasivayam en Van Lieshout (2011) het samenspel zien van spraakmotorische vaardigheid, specifieke niet-motorische factoren die een beroep doen op deze spraakmotorische vaardigheid en compensatiemogelijkheden (grotere spraakbewegingen) waardoor spraakmotorische stabiliteit aanwezig blijft. Dit zowel bij personen met sterkere spraakmotorische vaardigheden (PNS) als personen met meer beperkte spraakmotorische vaardigheden (PDS). Het bovenste paneel van het diagram toont drie factoren waarvan wordt verondersteld dat ze de amplitude ("grootte") van de (articulatie)beweging mede beïnvloeden: linguïstische, cognitieve en emotionele factoren. Bijvoorbeeld, langere zinnen worden gemiddeld genomen sneller uitgesproken dan kortere en boosheid heeft vaak effect op de grootte van de spraakbewegingen - deze kunnen kleiner of groter worden. Een persoon die stottert (PDS) zal bij een bepaalde waarde van de niet-motorische factoren vaker onvloeiend spreken als deze kleine spreekbewegingen maakt. Iemand die niet stottert (PNS), iemand met sterkere spraakmotorische vaardigheden dus, kan in die situatie wel vloeiend spreken. Echter, als de PDS grotere spraakbewegingen maakt blijkt deze veel vloeiender te spreken. De auteurs verklaren dit als volgt. Grotere bewegingen geven meer (afferente) kinesthetische feedback, zodat de hierboven genoemde kritische drempelwaarde wordt gehaald: de koppelingen tussen afferente en efferente signalen blijven stabiel. In deze benadering kan dus worden verklaard waarom een spreker met meer beperkte spraakmotorische vaardigheden (PDS) in bepaalde condities niet, maar in andere situaties wel een stabiele spraakmotoriek houdt.

We eindigen met het model van De Nil (2012; 1999), waarvan wij menen dat hierin recente ontwikkelingen compleet en ook eenvoudig zijn weergegeven. Terwijl de meeste andere modellen zich vooral richten op het verklaren van optredende, individuele stotters, is dit model eerder gericht op het verklaren van de algemene ontwikkeling van stotteren de conditie stotteren. Het model is gebaseerd op de gedachte dat kinderen door genetische invloeden en hersenontwikkeling een minder sterke sensomotoriek hebben die leidt tot instabiele spraak. Voor de meeste kinderen zal dit niet voldoende zijn voor de ontwikkeling van stotteren, maar andere factoren (zoals an sich niet ernstige taalachterstand, temperament en omgevingsfactoren) kunnen een goede ontwikkeling van vloeiende spraak bemoeilijken. Ook ziekte of situationele omstandigheden kunnen het ontstaan van stotteren mede veroorzaken. Omdat niet alle kinderen in dergelijke omstandigheden gaan stotteren, moet een (genetische?) predispositie wel aanwezig zijn. Na het begin van stotteren kan de ontwikkeling twee kanten uitgaan. De meerderheid van de kinderen zullen spontaan (door maturatie) of met enige hulp herstellen en een vloeiende spraak gaan ontwikkelen. Sommige kinderen zullen (ongeacht bovengenoemde helpende factoren) toch blijven stotteren. In dit model kan dat gebeuren indien de kinderen minder in staat zijn om nieuwe motorische vaardigheden te leren. Hierdoor kan er een meer gespannen aandacht op de spraak ontstaan, met vooral negatieve gevolgen. Verschillende versterkende factoren zijn in het model aangegeven. Al deze factoren zullen, samen of apart, het voor het kind dat al erfelijk belast is, lastig maken om vloeiende spraak te ontwikkelen. Het model is natuurlijk een simplificatie, maar geeft wel aan langs welke wegen een geschikte therapie kan worden overwogen. Zo kan de therapeut zich samen met het kind richten op de sensomotorische ontwikkeling in spreektechnische zin of meer op coping strategieën en/of cognitieve acceptatie. In de praktijk zal 
de therapeut meestal een goede combinatie van al deze verschillende methodieken uit de kast halen, passend voor het kind zelf.

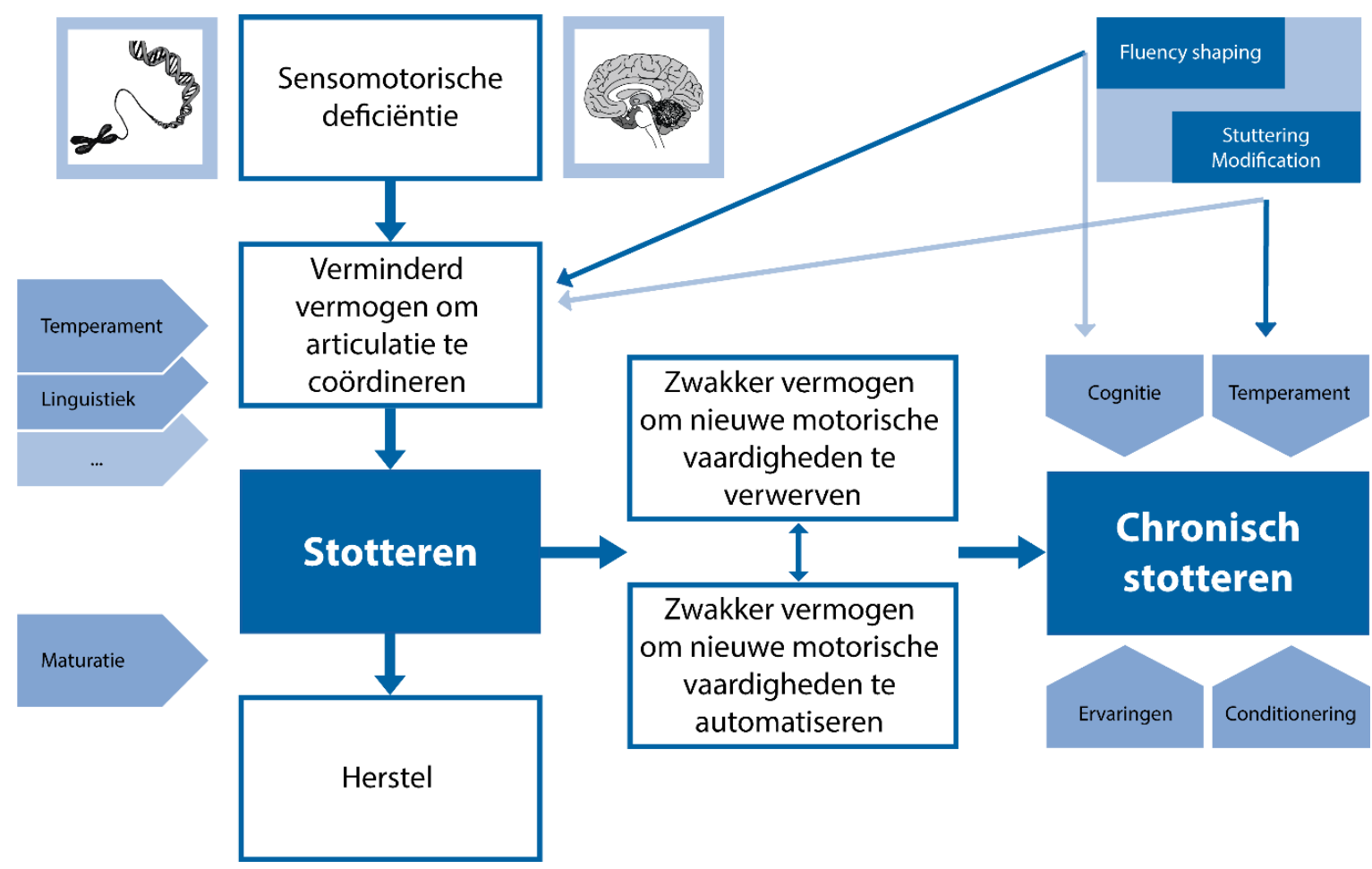

Figuur 6: Ontstaan en ontwikkeling van stotteren (naar de Nil, 2012). Het model van Luc de Nil toont de ontwikkeling van stotteren tezamen met factoren die een invloed uitoefenen tijdens het ontstaan en de verdere evolutie van stotteren. De spraakonvloeiendheden die tot de diagnose stotteren leiden zijn het kenmerk van een basale sensomotorische stoornis in de spraakcontrole. Verschillende factoren, zoals taal, temperament, en omgevingsinvloeden, dragen bij tot de verdere ontwikkeling van stotteren. Maturatie en omgevingsfactoren kunnen leiden tot het herstel van stotteren, terwijl bijkomende zwakheden in het ontwikkelen van motorische vaardigheden kunnen leiden tot het ontwikkelen van persisterend stotteren.

Zoals aangegeven beogen we niet een allesomvattend overzicht van de huidige bestaande modellen te geven. We hebben een paar nogal van elkaar verschillende modellen gepresenteerd. Dit geeft al aan dat een alles omvattend model niet makkelijk te maken is. Het klinisch bruikbare model dat we voorstellen wordt in het volgende artikel verder uitgewerkt en gepresenteerd. Wij beogen hier vooral een aansprekende visualisatie in te bouwen, met aandacht voor de veelheid van interacties op diverse te onderscheiden, maar toch samenhangende domeinen, en gebaseerd op de meest recente inzichten. Vooral de gemakkelijke uitleg in de praktijk beogen wij na te streven. 


\section{Discussie}

Berichten uit de dagelijkse praktijk van vooral Nederlandstalige logopedisten (-stottertherapeuten) leerden ons dat een revisie van het min of meer gangbare klinische werkmodel van Bertens ( 1994; 2017) nodig was. Recent onderzoek toont geen bewijs voor een neuromusculaire timingsstoornis als onderliggende oorzaak van stotteren (zoals in het model van Bertens wordt gesteld). Evenmin is er bij mensen die stotteren bewijs voor een dergelijke timingsstoornis in algemene zin (bij andere motorische activiteiten dan spreken). De genetische basis van stotteren die aan neurologische verschijnselen ten grondslag kunnen liggen, wordt tegenwoordig meer in beeld gebracht. Alhoewel er nog veel vragen niet opgehelderd zijn, gaan de recente modellen (hierboven zijn een paar daarvan aangehaald) wel (minder of meer) van deze nieuwe inzichten uit. Ook incorporeren recente modellen veel meer dan het model Bertens de processen van regulatie en terugkoppeling hoe deze processen dan ook exact plaatsvinden. In box 1 worden deze genetische en regulatoire aspecten uitgelegd aan een ander meer aansprekend ziektebeeld, namelijk astma.

Wij menen hier aan de gesignaleerde behoefte te voldoen door een korte beschrijving te geven van de processen die bij stotteren optreden. Dit is duidelijk niet bedoeld als een review, maar meer om aan te geven dat er iets diepers speelt dan een timingsstoornis, en dient vooral als tutoriale opmaat voor het volgende hoofdstuk. We hebben een beperkt aantal recente werkmodellen kort besproken. Er is geen uitputtende beschrijving van alle modellen nagestreefd. In veel modellen zijn de recente biologische en vaak ook regulatoire inzichten wel verwerkt, maar omdat er meerdere modellen zijn, is kennelijk het ontwerpen van een allesomvattend makkelijk bruikbaar werkmodel lastig.

Terwijl al deze modellen bruikbare aspecten hebben, menen we dat het hierboven besproken model van de Nil, de makkelijkste basis geeft voor een ons inziens bruikbaar werkmodel voor in de spreekkamer. In goed overleg hebben we dat laatste model daarom nog verder ontwikkeld, en we geven het in de hierna volgende publicatie.

\section{Literatuur}

Alm, P. A. (2014). Stuttering in relation to anxiety, temperament, and personality: review and analysis with focus on causality. Journal of Fluency Disorders, 40, 5-21.

Ambrose, N. G., Yairi, E., Loucksa, T. M., Seery C. H., \& Throneburg, R. (2015) Relation of motor, linguistic and temperament factors in epidemiologic subtypes of persistent and recovered stuttering: Initial findings. Journal of Fluency Disorders, 45, 12-16.

Arenas, R.M. (2016). Conceptualizing and investigating the contextual variability of stuttering: The speech and monitoring interaction (SAMI) framework. Speech, Language and Hearing, 20 (1), 15-28, https://doi.org/10.1080/2050571X.2016.1221877

Barnes, D.T., Wozniak, D.F., Gutiertez, J. Han, T., Drayna, D. \& Holy, T.E. (2016). A Mutation Associated with Stuttering Alters Mouse Pup Ultrasonic Vocalizations. Current Biology, https://doi.org/10.1016/j.cub.2016.02.068

Bastiaens, M., Ter Huurne, J., Gruis, N., Bergman, W., Westendorp, R., Vermeer, B \& Bouwes 
Bavinck, J. (2001). The melanocortin-1-receptor gene is the major freckle gene. $\mathrm{Hu}$ man Molecular Genetics, 10-16, 1701-1708, https://doi.org/10.1093/hmg/10.16.1701

Bauerly, K. R., \& Luc, F. (2011). Speech sequence skill learning in adults who stutter. Journal of Fluency Disorders, 36(4), 349-360.

Beal, D.S., Gracco, V.L., Brettschneider J., Kroll, R.M. \& De Nil, L.F. (2013). A voxel-based morphometry (VBM) analysis of regional grey and white matter volume abnormalities within the speech production network of children who stutter. Cortex, 49-8, 21512161, https://doi.org/10.1016/j.cortex.2012.08.013

Beal, D. S., Quraan, M. A., Cheyne, D. O., Taylor, M. J., Gracco, V. L., \& De Nil, L. F. (2011). Speech-induced suppression of evoked auditory fields in children who stutter. $\mathrm{Neu}$ roImage, 54(4), 29943003. https://doi.org/10.1016/j.neuroimage.2010.11.026

Benito-Aragón, C., Gonzalez, R., Lidell, T., Diez, I., d'Oleire Uquillas, F. Ortiz-Teran, L, ... Sepulcre, J. (2020). Neurofilament-lysosomal genetic intersections in the cortical network of Stuttering. Progress in Neurobiology,

https://doi.org/10.1016/j.pneurobio.2019.101718

Bertens, A. (1994). The beauty of simplicity. Proceedings 1st World Congress on Fluency Disorders. August 812, 571575, Nijmegen, University Press.

Bertens, A. (2017). De essentie van stotteren. NTVL, 89, 3, 18-19.

Bloodstein, O., \& Bernstein Ratner, N. (2008). A Handbook on stuttering. Delmar: Clifton Park.

Bottema, R.W.B., Kerkhof, M., Reijmerink, N.E., Oosterhout van, A.J., Postma, D.S. \& Koppelman, G.H. (2010). Gene-gene interaction in regulatory Tcell function in atopy and asthma development in childhood. Mechanisms of allergy and clinical immunology, 126 (2), 338-346, https://doi.org/10.1016/j.jaci.2010.04.024

Chang, S., Garnett, E.O., Etchell, A. \& Ho Ming Chow, H.M. (2019). Functional and neuroanatomical bases of developmental stuttering: current insights. Neuroscientist, 12, 25(6), 566-582, https://doi.org/10.1177/1073858418803594

Chang, SE., Erickson, K.I., Ambrose, N.G., Hasegawa-Johnson, M.A. \& Ludlow, C.L. (2008), Brain anatomy differences in childhood stuttering. Neuroimage, 39 (3), 1333-1344, https://doi.org/10.1016/j.neuroimage.2007.09.067

Chang, S. \& Zhu, D.Z. (2013). Neural network connectivity differences in children who stutter. Brain, 136(12), 3709-3726. https//:doi/10.1093/brain/awt275

Chow, H.M. \& Chang, S.E. (2017). White matter developmental trajectories associated with persistence and recovery of childhood stuttering. Human Brain Mapping. doi: $10.1002 / \mathrm{hbm} .23590$

Chow, H.M. \& Chang, S-E. (2021, 1 juli). Imaging Genetic research in stuttering: Connecting the dots. https://www.theifa.org/research/science-outreach/697-imaging-geneticsresearch-in-stuttering-connecting-the-dots

Conture, EG.; Walden, T. A. (2012). Dual diathesis-stressor model of stuttering. In: Bellakova, L.; Filatova, Y., editors. Theoretical issues offluency disorders. Moscow: Vlados.

Conture, E., Walden, T., Graham, C., Arnold, H., Hartfield, K., and Karrass, J. (2006). Communication - emotional model of stuttering. In N. Bernstein Ratner and J. Tetnowski (Eds.) (pp. 17-46), Stuttering Research and Practice Volume 2: Contemporary Issues 
and Approaches. Mahwah, NJ: Lawrence Erlbaum Associates.

Daliri, A., Prokopenko, R.A., Flanagan, J.R. \& Max, L. (2014) Control and prediction components of movement planning in stuttering versus nonstuttering adults. Journal of Speech, Language, and Hearing Research, 57 (6), 2131-2141.

De Nil, L.F. (1999). Stuttering: A neurophysiological perspective. In: Bernstein Ratner \& E. C. Healey. Stuttering research and practice: Bridging the gap. 85-102

De Nil, L. F. (2012). Spreekvloeienheid stoornissen. A review of brain imaging research in stuttering: new insights into to onset and development of stuttering and some clinical implications. Themanummer Logopedie, juli-augustus, 41-52

Drayna, D. \& Kang, C. (2011). Genetic approaches to understanding the causes of stuttering. Journal of Neurodevelopmental Disorders, 3, 374-380

DSM-5 (2016). Handboek voor de classificatie van psychische stoornissen (DSM-5). Nederlandse vertaling van Diagnostic and Statistical Manual of Mental Disorders 5th Edition. Arlington: American Psychiatric Association

Dworzynski, K., Remington, A., Rijsdijk, F., Howell, P. \& Plomin, R. (2007). Genetic Etiology in Cases of Recovered and Persistent Stuttering in an Unselected, Longitudinal Sample of Young Twins. American Journal of Speech-Language Pathology, 16, 169-178.

Eggers, K., De Nil, L., \& Van den Bergh, B. R. (2010). Temperament dimensions in stuttering and typically developing children. Journal of Fluency Disorders, 35, 355-372.

Etchell, A.C., Civier, O., Ballard, K.J. \& Sowman, P.F. (2017). A systematic literature review of neuroimaging research on developmental stuttering between 1995 and 2016. Journal of Fluency disorders, https//:doi: 10.1016/j.jfludis.2017.03.007

Fagnani, C., Fibiger, S. , Skytthe, A. \& Hjelmborg, J.V.B. (2011). Heritability and environmental effects for self-reported periods with stuttering: A twin study from Denmark. Logopedics, Phoniatrics, Vocology, 36, 3, https://doi.org/10.3109/14015439.2010.534503

Fedyna, A., Drayna, D. \& Kang, C. (2011). Characterization of a mutation commonly associated with persistent stuttering: evidence for a founder mutation. Journal of Human Genetics, 56, 80-82.

Foundas, A.L., Corey, D.M., Angeles, V., Bollich, A.M., Crabtree-Hartman, E. \& Heilman, K.M. (2010). Atypical cerebral laterality in adults with persistent developmental stuttering. Neurology, https://doi: 10.1212/01.wnl.0000094320.44334.86.

Frigerio-Domingues, C.E. \& Drayna, D. (2017). Genetic contributions to stuttering: the current evidence. Molecular Genetics \& Genomic Medicine, doi: 10.1002/mg.g3.276

Frigerio-Domingues C.E, Gkalitsiou Z, Zezinka A, Sainz E, Gutierrez J, Byrd C, Webster R, \& Drayna D. (2019). Genetic factors and therapy outcomes in persistent developmental stuttering. Journal of Communication Disorders https://doi.org/10.1016/j.jcomdis.2019.03.007

Frigerio-Domingues, C., Han, T-U \& Drayna D. (2021, 1 augustus). Genetic factors and their action in persistent stuttering.

https://www.theifa.org/ja/research/science-outreach/651-genetic-factors-and-theiraction-in-persistent-stuttering

Garnett, E.O., Chow, H.M., Nieto-Castañón, A. , Tourville, J.A., Guenther, F.H. \& Chang, S.(2018). Anomalous morphology in left hemisphere motor and premotor cortex of 
children who stutter. Brain, 141 (9), 2670-2684, https://doi.org/10.1093/brain/awy199 Gerwin K.L. \& Weber, C. (2020). Neural Indices Mediating Rhyme Discrimination Differ for Some Young Children Who Stutter Regardless of Eventual Recovery or Persistence. Journal of Speech Language and Hearing Research,. 63(4), 1053-1070, https://pubmed.ncbi.nlm.nih.gov/32302258/

Halag-Milo, T., Stoppelman, N., Kronfeld-Duenias, V., Civier, O., Ami,r O., Ezrati-Vinacour, R. \& Ben-Shachar, M. (2016). Beyond production: Brain responses during speech perception in adults who stutter. Neuroimage Clin., 3-11, 328-338, https://doi: 10.1016/j.nicl.2016.02.017

Han, T., Root, J., Reyes, L.D., Huchinson, E.B., Hoffmann du, J., Lee, W., Barnes, T.D. \& Drayna, D.(2019). Human GNPTAB stuttering mutations engineered into mice cause vocalization deficits and astrocyte pathology in the corpus callosum. PNAS, www.pnas.org/cgi/doi/10.1073/pnas.1901480116

Hilger, A.I., Zelaznik, H. \& Smith, A. (2016). Evidence That Bimanual Motor Timing Performance Is Not a Significant Factor in Developmental Stuttering. Journal of Speech, Language, and Hearing Research, 59(4), 674-685, https://doi.org/10.1044/2016_JSLHR-S15-0172

ICD-11, International Classification of Diseases, 11th Revision. verkregen van https://icd.who.int/browse11/l-m/en\#/http://id.who.int/icd/entity/654956298

Kang, C. , Riazuddin. S., Mundorff. J., Krasnewich, D., Friedman, P., Mullikin. J.C., Drayna, D. (2010). Mutations in the lysosomal enzyme-targeting pathway and persistent stuttering. N. Engl. J. Med., 362, 677-685.

Kefalianos, E., Onslow, M., Ukoumunne, O.,Block, S. \& Reilly, S. (2014). Stuttering, Temperament, and Anxiety: Data From a Community Cohort Ages 24 Years. Journal of Speech, Language, and Hearing Research, 57, 1314-1322.

Kefalianos, E., Onslow, M., Packman, A., Vogel, A., Pezic, A., Mensah, F, Reilly, S. (2017). The History of Stuttering by 7 Years of Age: Follow-Up of a Prospective Community Cohort. Journal of Speech Language and Hearing Research, 60(10), 2828-2839.

Kim, K.S., Daliri, A., Flanagan, J.R. \& Max, L.(2020). Dissociated Development of Speech and Limb Sensorimotor Learning in Stuttering: Speech Auditory-motor Learning is Impaired in Both Children and Adults Who Stutter. Neuroscience, 451, 1-21.

Kleinow, J. \& Smith, A. (2000) Influences of length and syntactic complexity on the speech motor stability of the fluent speech of adults who stutter. Journal of Speech Language and Hearing Research., 43 (2), 548-559, https://doi.org/10.1044/jslhr.4302.548

Knecht, S., Deppe, M., Dräger, B., Bobe, L., Lohmann, H., Ringelstein, E. B., \& Henningsen, H. (2000). Language lateralization in healthy right-handers. Brain, 123(1), 74-81.

Koenraads, S. \& Franken, M. (2018). De hersenontwikkeling bij kinderen die stotteren: een seminar van onderzoeker Soo-Eun Chang. Stem-, Spraak- en Taalpathologie, 23, 1-8.

Koenraads e.a. (2019). Stuttering and gray matter morphometry: A population-based neuroimaging study in young children. Brain Lang; 194:121-131.

Koenraads, S.P.C., Van der Schroeff, M.P., Van Ingen, G., Lamballais, S., Tiemeier, H., Baatenburg de Jong, R.J. . . . Muetzel, R.L.(2020). Structural brain differences in pre - adolescents who persist in and recover from stuttering. NeuroImage: Clinical, 27, 
https://doi.org/10.1016/j.nicl.2020.102334

Koenraads, S.P.C., Jansen, P.W., de Jong, R.J.B., van der Schroeff, M.P., Franken, M.C. (2021) Bidirectional Associations of Childhood Stuttering With Behavior and Temperament. J Speech Lang Hear Res. Nov 4:1-17. doi: 10.1044/2021_JSLHR-20-00252. Epub ahead of print. PMID: 34735297.

Korzeczek , A., Cholin, J., Jorschick, A., Hewitt, M \& Sommer, M. (2020). Finger Sequence Learning in Adults Who Stutter. Front Psychol, https:// doi: 10.3389/fpsyg.2020.01543

Kraft, S. J., \& DeThorne, L. S. (2014). The brave new world of epigenetics: Embracing complexity in the study of speech and language disorders. Current Developmental Disorders Reports, 1(3), 207-214

Lenoci, G. \& Ricci, I. (2018). An ultrasound investigation of the speech motor skills of stuttering Italian children. Clin Linguist Phon, https:// DOI: 10.1080/02699206.2018.1510983

Madrid-Valero, J.J., Rubio-Aparicio, M., Gregory, A.M., Sánchez-Meca, J. \& Ordoñana, J.R. (2021). The heritability of insomnia: Systematic review and meta-analysis of twin studies. Sleep Med Rev, https://pubmed.ncbi.nlm.nih.gov/33556853/

Max, L. \& Daliri , A. (2019). Limited Pre-Speech Auditory Modulation in Individuals Who Stutter: Data and Hypotheses. J Speech Lang Hear Res, 62(8S), 3071-3084, https://doi: 10.1044/2019_JSLHR-S-CSMC7-18-0358

Mersov, A., Cheyne, D., Jobst, C., \& De Nil, L. (2018). A preliminary study on the neural oscillatory characteristics of motor preparation prior to dysfluent and fluent utterances in adults who stutter. Journal of Fluency Disorders, 55, 145-155

Mukherjee, A.B. \& Zhang, Z. (2011). Allergic Asthma: Influence of Genetic and Environmental Factors. The Journal of Biological Chemistry, 286 (38), 3288332889, https://doi.org /10.1074/jbc.R110.197046

Myers, R.H. (2004). Huntington's disease genetics, NeuroRX, 1, 255262.

Namasivayam, A.K. \& Van Lieshout, P.(2008). Investigating speech motor practice and learning in people who stutter. Journal of Fluency Disorders, 33(1), 32-51.

Namasivayam., AK \& Van Lieshout, P. (2011). Speech Motor Skill and Stuttering. Journal of Motor Behavior, 43 (6), 477-489.

Nippold, M. A. (2012). Stuttering and Language Ability in Children: Questioning the Connection. American Journal of Speech-Language Pathology, 21, 183-196.

Ntourou, K., Conture, E. G., \& Lipsey, M. W. (2011). Language Abilities of Children Who Stutter: A Meta-Analytical Review. American Journal of Speech-Language Pathology, 163-179.

NVLF (2020). Richtlijn stotteren bij kinderen, adolescenten en volwassenen. Nederlandse Vereniging voor Logopedie en Foniatrie,

https://www.nvlf.nl/cms/showpage.aspx?id=312

ObermayerPietsch, B.M., Bonelli, C.M., Walter, D.E., Kuhn, R.J., FahrleitnerPammer, A., Berghold, A. . . . Renner,W. (2009). Genetic Predisposition for Adult Lactose Intolerance and Relation to Diet, Bone Density, and Bone Fractures. jbmr, https://doi.org/10.1359/jbmr.0301207

Olander, L., Smith, A. \& Zelaznik, H. (2010) Evidence That a Motor Timing Deficit Is a Factor 
in the Development of Stuttering. Journal of Speech Language and Hearing Research, 53(4), 876-886, https://doi.org/10.1044/1092-4388

Oonk, L.C. \& Busser, A.G.M. (2022). Richtlijn stotteren 2020: wat er is veranderd en waarom. Stem-, Spraak- en Taalpathologie, 27.

Oonk, L.C., Franken, M.C., de Nil, L., Bouwen, J., van der Vlist, A. \& Bast, B.J.E.G. (2022). Ontstaan en ontwikkeling van stotteren: voorstel praktijkmodel. Stem-, Spraak- en Taalpathologie, 27, 28-40.

Packman, A. (2012). Theory and therapy in stuttering: A complex relationship. Journal of Fluency Disorders, 37(4), 225-233, https:// DOI: 10.1016/j.jfludis.2012.05.004

Packman, A., \& Attanasio, J. S. (2010). A model of the mechanisms underpinning early interventions for stuttering. Seminar presentation at the annual convention of the American Speech-Language and Hearing Association Philadelphia, USA.

Poulos M.G. \& Webster W.G. (1991). Family history as a basis for subgrouping people who stutter. Journal of Speech Language and Hearing Research, 34-1, 5-10.

doi: 10.1044/jshr.3401.05. PMID: 2008081.

Ptak, C. \& Petronis, A. (2010). Epigenetic approaches to psychiatric disorders. Dialogues Clin Neurosci., 12(1), 25- 35.

Raza, M.H., Domingues C.E., Webster R., Sainz E., Paris E., Rahn R., Drayna, D. (2016). Mucolipidosis types II and III and non-syndromic stuttering are associated with different variants in the same genes. Eur. J. Hum. Genet., 24, 529-534.

Raza, M.H., Mattera, R. Morell, R., Sainz, E., Rahn, R., Gutierrez, J., Drayna, D. (2015). Association between Rare Variants in AP4E1, a Component of Intracellular Trafficking, and Persistent Stuttering. The American Journal of Human Genetics, 97, 715-725.

Reilly, S., Onslow, M., Packman, A., Cini, E., Conway, L., Ukoumunne, O. C., e.a. (2013). Natural History of Stuttering to 4 Years of Age: A Prospective Community-Based Study. Pediatrics, 460-467.

Reijmerink N. E., Bottema, R. W. B., Kerkof, M., Gerritsen, J., Stelma, F.F., Thijs, C. Postma, D.S. (2010). TLRrelated pathway analysis: novel genegene interactions in the development of asthma. Allergy, 65, 199- 207, https://doi.org/10.1111/j.1398-9995.2009.02111.x

Sares, A.G., Deroche, M.L.D., Shiller, D.M. \& Gracco, V.L. (2019). Adults who stutter and metronome synchronization: evidence for a nonspeech timing deficit. Annals of the New York Academy of Sciences, 1449 (1), 56-69.

Silventoinen, K., Sammalisto, S., Perola, M., Boomsma, D., Cornes, B., Davis, C., Dunkel, L., De Lange, M., Harris, J., Hjelmborg, M., Luciano, M., Martin, G., Mortensen, J., Nisticò, L., Pedersen, N., Skytthe. A., Spector, T., Stazi, M.A., Willemsen. G. \& Kaprio, J.(2003). Heritability of adult body height: a comparative study of twin cohorts in eight countries. Twin Res, https://pubmed.ncbi.nlm.nih.gov/14624724/

Singer C.M., Hessling A., Kelly E.M., Singer L., \& Jones R.M.(2020) Clinical Characteristics Associated With Stuttering Persistence: A Meta-Analysis. Journal of Speech Language and Hearing Research, 63(9), 2995-3018. doi: 10.1044/2020_JSLHR-20-00096

Smith, A., \& Kleinow, J. (2000). Kinematic correlates of speaking rate changes in stuttering and normally fluent adults. Journal of Speech Language and Hearing Research, 43(2), 
521-536, doi: 10.1044/jslhr.4302.521. PMID: 10757701.

Smith, A., \& Weber, C. (2016). Childhood stuttering: Where are we and where are we going? Seminars in Speech and Language, 37, 4, 291-297.

Smith, A. \& Weber, C. (2017). How Stuttering Develops: The Multifactorial Dynamic Pathways Theory. Journal of Speech Language and Hearing Research, 60, 24832505.

Smits-Bandstra, S., Luc, F., \& Saint-Cyr, J. A. (2006). Speech and nonspeech sequence skill learning in adults who stutter. Journal of fluency disorders, 31(2), 116-136.

Sonneville-Koedoot de C., Stolk E., Rietveld T. \& Franken M.C. (2015). Direct versus Indirect Treatment for Preschool Children who Stutter: The RESTART Randomized Trial. PLoS ONE, 10(7), e0133758. https://doi:10.1371/journal.pone.0133758.

Susanto, N.H., Vicendese, D., Salim, A., Lowe, A.J., Dharmage, S.C., . . . Erbas, B. (2017). Effect of season of birth on cord blood IgE and IgE at birth: A systematic review and meta-analysis. Environmental Research, https:// doi: 10.1016/j.envres.2017.05.026

Tick, B., Molton, P., Happé F., Rutter, M. \& Rijsdijk, F. (2015). Heritability of autism spectrum disorders: a meta-analysis of twin studies. J Child Psyhol Psychiatry.

Usler E., Smith A. \& Weber C. (2017). A Lag in Speech Motor Coordination During Sentence Production Is Associated With Stuttering Persistence in Young Children. Journal of Speech Language and Hearing Research, 60, 51-61, https://doi.org/10.1044/2016_JSLHRS-15-0367

Usler, E.R. \& Walsh, B. (2018). The Effects of Syntactic Complexity and Sentence Length on the Speech Motor Control of School-Age Children Who Stutter. Journal of Speech Language and Hearing Research, 61(9), 2157-2167, https://doi.org/10.1044/2018_JSLHR-S-17-0435

Van Beijsterveldt, C., Felsenfeld, S. \& Boomsma, D. (2010). Bivariate Genetic Analyses of Stuttering and Nonfluency in a Large Sample of 5-Year-Old Twins. Journal of Speech Language and Hearing Research Research, 53, 609619.

Van Lieshout P.H.H.M. \& Hulstijn W (2004). In: Maassen, B., Kent R.D., Peters H.F.M. (red.), . . Speech motor Control in Normal and Disordered Speech (h 13). Oxford University Press.

Van Lieshout, P., Hulstijn, W. \& Peters, H. (2004). Searching for the weak link in the speech production chain of people who stutter: A motor skill approach. In: B. Maassen e.a.(ed), Speech motor control in normal and disordered speech (pp.313-355). Oxford: Oxford University Press.

Van Riper, C. (1990). Final thoughts about stuttering. Journal of Fluency Disorders, 15, 317318

Van de Vorst, R. \& Gracco, V.L. (2018). Is stotteren een spraak-motorische timingstoornis? Een alternatieve geïntegreerde benadering volgens het SAMI-model. Stem-, Spraaken Taalpathologie, 23, 39-62.

Walden, T.A., Frankel, C.B., Buhr, A.P., Johnson, K.N., Conture, E.G. \& Karrass, J. M. (2012). Dual Diathesis-Stressor Model of Emotional and Linguistic Contributions to Developmental Stuttering. J Abnorm Child Psychol, 40, 633644, https://doi.org/10.1007/s10802-011-9581-8

Watkins, R.V., Yairi, E. \& Ambrose, N.G. (1999). Early childhood stuttering III: initial status 
of expressive language abilities. Journal of Speech Language and Hearing Research, https://DOI: 10.1044/jslhr.4205.1125

Watts A., Eadie P., Block S., Mensah F. \& Reilly S. (2015). Language ability of children with and without a history of stuttering: A longitudinal cohort study. International Journal of Speech-Language Pathology, 17:1, 86-95, https://DOI: 10.3109/17549507.2014.923512

Watts, A., Eadie, P., Block, S., Mensah, F., \& Reilly, S. (2017). Language skills of children during the first 12 months after stuttering onset. Journal of Fluency Disorders, 51, 3949.

Williamson, M. M. (1998). Neural control of rhythmic arm movements. Neural Networks, 11,13791394

Yairi, E., \& Ambrose, N. (2013). Epidemiology of stuttering: 21st century advances. Journal of Fluency Disorders, 38, 66-87. https://doi.org/10.1016/j.cub.2016.02.068

Yairi, E., \& Seery, C.H. (2011). Stuttering. Foundations and Clinical Applications. New Jersey: Pearson. 